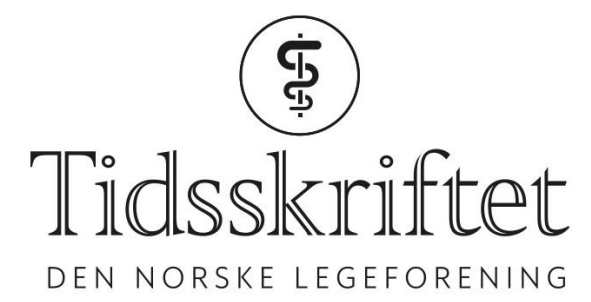

\title{
«Hvileskjær» i pandemien må brukes til bedre planlegging for de eldste
}

KRONIKK

TORGEIR BRUUN WYLLER

E-post: t.b.wyller@medisin.uio.no

Torgeir Bruun Wyller er spesialist i indremedisin og i geriatri, overlege og professor ved Geriatrisk avdeling, Oslo universitetssykehus.

Forfatteren har fylt ut ICMJE-skjemaet og oppgir ingen interessekonflikter.

Et formål med å «flate ut kurven» for covid-19-pandemien er å vinne tid, så helsevesenet kan forberede seg. Skrøpelige eldre kan ha mye å vinne på at vi bruker tiden godt.

Jeg ser fem områder som krever rask planlegging og betydelig innsats dersom vi skal unngå at pandemien blir like katastrofal for de eldste i Norge som vi har sett eksempler på i andre land (1).

\section{Seleksjon til intensivbehandling}

Det er ikke riktig å utsette pasienter for inngripende og ofte plagsom behandling som ikke er til nytte for dem. Både intensivleger (2) og geriatere (3) har forbilledlig påpekt dette i offentligheten. I begge fagmiljøer er det enighet om at frailty, som på norsk gjerne oversettes med «skrøpelighet», indikerer sannsynlig manglende nytte av intensivbehandling og er et bedre seleksjonskriterium enn alder (4). Skrøpelige pasienter har høy dødelighet av covid-19 fordi de er skrøpelige, ikke fordi det er mangel på respiratorer. Det gjelder også for dem som er blitt skrøpelige til tross for at de ikke er veldig gamle. Men skal dette resonnementet være gyldig, må det også kunne brukes omvendt: Gamle pasienter som ikke er skrøpelige, men derimot spreke (engelsk: fit), bør ikke nektes intensiv- eller respiratorbehandling på grunnlag av kronologisk alder (5). Muntlige rapporter fra flere sykehus tyder på at mange nå anvender kronologiske aldersgrenser for intensivbehandling av covid-19-pasienter. Hvis krisen blir prekær, kan vi bli tvunget til å prioritere dem som har flest gjenstående leveår. Men vi er langt fra den situasjonen foreløpig. Slik forholdene er nå, har vi mulighet til å intensivbehandle dem som har rimelig sjanse til komme igjennom det.

Skrøpelige pasienter har høy dødelighet av covid-19 fordi de er skrøpelige, ikke fordi det er mangel på respiratorer

Aftenposten meldte 6. april at av de snaut 200 pasientene som er intensivbehandlet for covid-19 i Norge til nå, er få over 70 år (6). Intensivdødeligheten er så langt gledelig mye lavere enn fryktet. Vi kan håpe det skyldes at smitten i Norge hittil i liten grad har nådd de eldste aldersgruppene. En alternativ og mindre hyggelig hypotese er at noen sykehus har begynt å selektere som om vi allerede hadde en kritisk mangel på intensivkapasitet. Ingen 
prognostiske faktorer er $100 \%$ treffsikre. Man må forvente at tross god skrøpelighetsscreening vil noen pasienter $\mathrm{d} ø$ under intensivbehandling. Hvis intensivdødeligheten er nær null, kan det være en mulig indikator på at seleksjonen er for streng og at bare de med best prognose får et tilbud.

\section{Palliativ behandling}

Skrøpelige covid-19-syke eldre vil ha høy dødelighet og skal ikke intensivbehandles. Derimot er det av kritisk betydning at de får tilfredsstillende palliasjon. Pasienter i terminalfasen av dødelig forløpende covid-19 kan være sterkt plaget, særlig av dyspné og angst, men også av høy feber med uttalt generell sykdomsfølelse. De palliative miljøene har publisert gode råd (7), men er alle med ansvar for terminalt syke covid-19-pasienter rustet til å følge dem? Trolig er den palliative behandlingen både i sykehus og sykehjem av varierende kvalitet, fra svært god - der man har et aktivt palliativt fagmiljø og tydelige faglige forbilder - til ganske dårlig enkelte andre steder. Mest bekymret er jeg for de som blir covid-19-syke som bor hjemme med uttalt skrøpelighet og mye hjemmetjenester. Hjemmetjenesten i enkelte norske kommuner er dessverre preget av manglende kontinuitet, faglig usikkerhet og språkproblemer. Slike steder er det usannsynlig at man skal klare å kombinere god lindrende behandling og tilfredsstillende smittevern.

I sin prioriteringsveileder skriver Helsedirektoratet at covid-19-syke sykehjemspasienter i hovedsak bør forbli i sykehjemmet og at skrøpelige hjemmeboende bør behandles av kommunale instanser (8). Formuleringene åpner for at dette prinsippet kan fravikes bl.a. hvis innleggelse i sykehus «vil gi økt livskvalitet». Det kan være svært relevant i en palliativ sammenheng. Det virker imidlertid som de fleste oppfatter rådet som mer kategorisk enn det er formulert, og nær sagt for enhver pris vil holde disse pasientene utenfor sykehusene. Også på dette feltet vil en avflating av pandemikurven gjøre at vi kan unngå de mest brutale prioriteringene. Da bør det sies tydelig at innleggelse i sykehus ikke bare er akseptabelt, men også anbefalt, dersom dette er nødvendig for å oppnå tilfredsstillende palliasjon.

\section{Forholdene i sykehjem}

Sars-CoV-2-viruset kan spre seg skremmende fort i sykehjem og gi høy dødelighet (9). Det er derfor av kritisk betydning å forsøke å holde smitten utenfor sykehjemmene, ha høy testaktivitet, isolere smittede og holde de ansatte smittefrie. Igjen tyder muntlige og usystematiske rapporter på at forutsetningene for dette varierer foruroligende mye. Noen sykehjem og kommuner har truffet adekvate tiltak, mens andre mangler smittevernutstyr, har dårlig kontroll på om personalet kan ha vært smitteeksponert, og mangler fremfor alt rutiner for å gi god demensomsorg kombinert med adekvat smittevern. Dette siste er svært krevende. Gode råd er publisert (10), men utfordringene kan ikke løses på en god måte uten tilstrekkelig bemanning med god kompetanse.

I sykehjem, der prevalensen av demens er svært høy, kan det lett oppstå situasjoner som er etisk tvilsomme, påfører pasientene ekstra lidelse og er belastende for personalet. Mangelen på smittevernutstyr i sykehusene har med rette vakt bekymring og er mye omtalt. I sykehjem kan slik mangel få enda mer dramatiske konsekvenser, men utstyrsmangelen der har ikke fått samme oppmerksomhet. Sykehusene har heldigvis fått forsikringer om at ekstrautgifter som følge av covid-19-pandemien vil bli dekket. Kommunene må få samme handlingsrom når det gjelder sykehjemmene, og kommunale ledere må legge stivbeint regelfortolkning og detaljstyring til side. Nå er det god helsefaglig kompetanse, god fagetikk og god skjønnsutøvelse som gjelder.

Kommunale ledere må legge stivbeint regelfortolkning og detaljstyring til side. Nå er det god helsefaglig kompetanse, god fagetikk og god skjønnsutøvelse som gjelder

Hvis vi nå får et «hvileskjær», må det brukes intensivt til å sette sykehjemmene i stand til å møte de utfordringene de vil stå overfor. De trenger folk, de trenger kompetanse, noen av dem trenger bygningsmessige endringer - og de trenger smittevernutstyr. Alt dette haster. 


\section{Besøksforbudet i helseinstitusjoner}

Det er lett å begrunne besøksforbudet. Det følger logisk av mitt forrige punkt. Likevel må vi innse at vi her står overfor to innbyrdes motstridende hensyn der den beste balansen bare kan finnes gjennom klok skjønnsutøvelse. Covid-19-syke pasienter har dødd uten pårørende til stede fordi besøksforbudet enkelte steder er blitt forvaltet kompromissløst. Det kan medføre så stor lidelse både for den døende og for de pårørende at det vanskelig lar seg forsvare selv om smittevernargumentene er aldri så gode. Nå har Helsedirektoratet presisert at døende normalt skal få ha pårørende hos seg også under pandemien (11). Det er bra. Det blir en ekstra utfordring for personalet å legge til rette for at slikt samvær kan gjennomføres med godt smittevern, men det må være en høyt prioritert oppgave. Også her må «hvileskjæret» brukes aktivt til å legge gode planer.

Det er også andre som lider urimelig sterkt under besøksforbudet. Det er kommet foruroligende rapporter om hvordan pasienter med alvorlig demens får dramatisk forverret uro, fortvilelse og atferdsforstyrrelser fordi de blir avskåret fra å møte sine nærmeste uten at det er mulig for dem å forstå årsaken. Personer med demens har blitt nektet å komme i sin ektefelles begravelse. Det er rapporter om personer som dør av andre ting enn covid-19 som utsettes for smitteverntiltak som for dem er irrelevante. Også her må vi foreta en klok avveining mellom to aktverdige, men til dels motstridende formål: Sårbare eldre skal ikke utsettes for unødig smitterisiko, men sårbare eldre (som ofte uansett har kort forventet gjenstående levetid) skal heller ikke utsettes for inngripende tiltak som gjør symptomtrykket fra kronisk og alvorlig sykdom større enn det allerede er. I enkelte tilfeller vil dispensasjon fra besøksforbudet være gunstig fra et smittevernsynspunkt, fordi det kan gjøre det lettere å få personer med demens til å holde seg i ro og ikke komme for nær medpasienter og personale.

Pasienter med alvorlig demens er blant samfunnets svakeste, uten mulighet til å tale sin egen sak og uten sterke talspersoner. Vår evne til å gi dem god omsorg også i en krisetid er en indikator på samfunnsmoralen. Det reises noen dilemmaer som kan synes uløselige, og der $100 \%$ lik behandling fra tilfelle til tilfelle neppe er ønskelig. De som skal forvalte besøksforbudet og i gitte tilfeller gi dispensasjon fra det, trenger retningslinjer å støtte seg til, men også nødvendig åpning for fleksibilitet.

Til nå har en av de mest bemerkelsesverdige konsekvensene av covid-19-pandemien vært at andre pasienter er 'blitt borte'

\section{Forsømmelse av andre tilstander}

Til nå har en av de mest bemerkelsesverdige konsekvensene av covid-19-pandemien vært at andre pasienter er «blitt borte». Dette er særlig bekymringsfullt for de skrøpelige eldre, som har høy prevalens av alvorlig organisk sykdom - ikke sjelden iatrogen - der adekvat behandling gir vesentlig prognosegevinst, men der symptomatologien kan være utydelig og lett misforstås som «bare et pleiebehov» (12). Det gis mange signaler om at folk helst bør holde seg borte fra sykehusene nå. Mange gamle, deres fastleger og legevaktleger kvier seg for å benytte spesialisthelsetjenesten, dels på grunn av smittefrykt og dels på grunn av frykt for å være i veien for mer «verdig trengende». Dermed blir det enda større fare enn ellers for at alvorlig og korrigerbar sykdom forsømmes og avspises med intensiverte omsorgstiltak i stedet for adekvat diagnostikk og behandling.

En intens pandemibekjempelse over noen få måneder ville betinget at omtrent alle andre hensyn ble satt til side. En kontrollert pandemiutvikling, kanskje over flere år, vil være lettere å håndtere, men stiller også større krav til at vi samtidig klarer å ivareta helsevesenets øvrige oppgaver. De skrøpelige eldre er blant dem som har mest å vinne på et adekvat helsetilbud, men er også blant dem som lettest vil falle utenfor. Vi trenger en plan for hvordan de skal ivaretas mens pandemien pågår. 
1. Sinvani L. The COVID-19 pandemic: experiences of a geriatrician-hospitalist caring for older adults. J Am Geriatr Soc 2020 doi: 10.1111/jgs.16481. [PubMed][CrossRef]

2. Flaatten H, Gundem T, Strand K et al. Ikke alle koronasyke skal ha intensivbehandling. Aftenposten 12.3.2020. https://www.aftenposten.no/meninger/kronikk/i/GGmn5m/ Lest 11.4.2020.

3. Mellingsæter M, Rostoft S, Pedersen R et al. Kan vi forberede oss på døden? Dagsavisen 30.3.2020. https://www.dagsavisen.no/debatt/1.1691283 Lest 11.4.2020.

4. Myrstad M, Ranhoff AH. Akutt syke eldre i koronaens tid. Tidsskr Nor Legeforen 2020; 140. doi: 10.4045/tidsskr.20.0227. [CrossRef]

5. White DB, Lo B. A framework for rationing ventilators and critical care beds during the COVID-19 pandemic. JAMA 2020 doi: 10.1001/jama.2020.5046. [PubMed][CrossRef]

6. Dommerud T, Skogstrøm L, Christensen M. Situasjonsrapport fra fire sykehus: Pasientene er yngre enn ventet. Aftenposten 6.4.2020. https://www.aftenposten.no/norge/i/LAEoJ4/ Lest 11.4.2020.

7. Brenne AT, Nordbø A, Steine S et al. Palliativ behandling av pasienter med covid-19. Tidsskr Nor Legeforen 2020; 140. doi: 10.4045/tidsskr.20.0276. [CrossRef]

8. Helsedirektoratet. Prioritering av helsehjelp i Norge under covid-19 pandemien. Notat 25.3.2020. https://www.helsedirektoratet.no/nyheter/prioritering-av-helsehjelp-i-norge-under-covid-19-pandemi en Lest 11.4.2020.

9. McMichael TM, Currie DW, Clark S et al. Epidemiology of covid-19 in a long-term care facility in King County, Washington. N Engl J Med 2020 doi: 10.1056/NEJMoa2005412. [PubMed][CrossRef]

10. Nasjonal kompetansetjeneste for aldring og helse. Behandling og omsorg i sykehjem. https://www.aldringoghelse.no/koronaviruset/sykehjem/ Lest 11.4.2020.

11. Dommerud T, Skogstrøm L. Helsemyndighetene om døende koronapasienter: - De pårørende skal få ta farvel. Aftenposten 11.4.2020. https://www.aftenposten.no/norge/i/9v4oEw/ Lest 11.4.2020.

12. Aronson L. Age, complexity, and crisis - a prescription for progress in pandemic. N Engl J Med 2020 doi:10.1056/NEJMp20o6115. [PubMed][CrossRef]

Publisert: 17. april 2020. Tidsskr Nor Legeforen. DOI: 10.4045/tidsskr.20.0325

Mottatt 12.4.2020, godkjent 16.4.2020.

(C) Tidsskrift for Den norske legeforening 2020. Lastet ned fra tidsskriftet.no 